\title{
A Humanização como "Estratégia de Gestão e Atenção" em Saúde?: uma Revisão de Literatura.
}

\author{
Silva, Marcos Vinícius Santos \\ IBPEX — viniciussilva.as@gmail.com
}

O presente estudo é fruto de uma pesquisa qualitativa, a partir de revisão de literatura sobre a temática Humanização na Saúde, tendo categorias de análise: humanização, saúde, gestão, atenção e democratização, sendo processadas nas bases de dados LILACS, Scielo, BVS e Google Acadêmico. Esta pesquisa buscou analisar, à luz das bibliografias produzidas, a gestão da Política Nacional de Humanização, na rede SUS, em especial, nos serviços da Atenção Básica. É importante frisar que a elaboração do estudo, emerge do entendimento da humanização na saúde como uma política estratégica, instrumento de mobilização social e institucional, instaurando uma nova dinâmica na esfera da saúde, pautada na qualificação dos serviços de saúde, na efetivação de novos processos de trabalho, pautados na indissociabilidade entre gestão e atenção. na busca por uma maior responsabilização de todos os agentes e entes envolvidos no processo de produção da saúde, na superação do ideal mercadológico que quantifica e unifica o sujeito/doença.

Silva, Marcos Vinícius Santos. A Humanização como "Estratégia de Gestão e Atenção" em Saúde?: uma Revisão de Literatura.. In: Anais do Congresso Internacional de Humanidades \& Humanização em Saúde [= Blucher Medical Proceedings, num.2, vol.1]. São Paulo: Editora Blucher, 2014. ISSN 2357-7282 DOI 10.5151/medpro-cihhs-10158 